\title{
Evaluation of lambda-cyhalothrin oxidative stress and gonad histoarchitecture toxicity potency in Clarias gariepinus
}

\author{
Samuel U. Ezenwosu', Emmanuel I. Nnamonu ${ }^{1 *}$ (D), Gregory Ejikeme Odo², Bright C. Ikele ${ }^{2}$ and Ogonna C. Ani ${ }^{3}$
}

\begin{abstract}
Background: Extensive and indiscriminate use of pesticides gradually destroys the environment (ecosystem), poses serious threats to human health, animal life (especially aquatic), plant forms, soil, water, and also lead to emergence of resilient species of life forms that are becoming resistant to pesticides. The present study focused on evaluating lambda-cyhalothrin oxidative stress and gonad histoarchitecture toxicity potency in Clarias gariepinus.

Results: A total of 120 C. gariepinus 16 to $40 \mathrm{~cm} \mathrm{SL}$ and 200 to $250 \mathrm{~g}$ bodyweights (assigned into treatments 0.00 (control), $2.5 \times 10^{-4} \mathrm{\mu g} / \mathrm{L}, 5.0 \times 10^{-4} \mathrm{\mu g} / \mathrm{L}$, and $6.25 \times 10^{-4} \mathrm{\mu g} / \mathrm{L}$ (A-D) lambda-cyhalothrin (LCT), each treatment consisted of 30 fishes, replicated three times, 10 fishes per replicate) were used for this study. On day 7 , catalase activity (CAT) and glutathione peroxidase (GPx) significantly increased $(p<0.05)$ in all treatments compared with control. Day 14 , superoxide dismutase (SOD) and GPx significantly increased $(p<0.05)$. All parameters significantly increased $(p<0.05$ ) on days 21 and 28 except SOD (day 21). All parameters increased significantly on day 28 across the row in all treatments. The significant increase $(p<0.05)$ in SOD, (malondialdehyde) MDA, GPx, and glutathione reductase (GR) levels returned to normal after 7 days of depuration but CAT level did not return to normal. The testes photomicrographs showed necrotic conditions in the spermatogenic cells with nuclear pyknosis and cytoplasmic swelling while that of the ovary displayed vacuolations, flabby oocytes, and degenerated ovaries changes.
\end{abstract}

Conclusion: Lambda-cyhalothrin is toxic to C. gariepinus. The inability of significant increase in CAT to return to normal after 7 days of depuration further confirms our report.

Keywords: Lambda-cyhalothrin, Clarias gariepinus, Oxidative stress biomarkers, Gonad-histology

\section{Background}

Extensive and indiscriminate use of pesticides gradually destroys the environment (ecosystem), poses serious threats to human health, animal life (especially aquatic), plant forms, soil, water, and also lead to emergence of resilient species of life forms that are becoming resistant to pesticides (Maton, Dodo, Nesla, \& Ali, 2016). However, those pesticides that have been reported to be moderately toxic to mammals such as lambda-

\footnotetext{
* Correspondence: emmanuel.nnamonu@fceehamufu.edu.ng

'Department of Biology, Federal College of Education, Eha-Amufu, Enugu

State, Nigeria

Full list of author information is available at the end of the article
}

cyhalothrin are most patronized by farmers. The toxicity of pesticides to biological systems has been reported. Ling et al. (2008) reported that pesticides induced alterations in testicular functions. DNA disintegration has been reported to have been caused by pesticides induced oxidative stress (Anadon, Martinez, Martinez, Diaz, \& Martinez-Larranaga, 2006; Ratnasooriya, Ratnayake, \& Jayatunga, 2003).

Lambda-cyhalothrin (LCT) as a synthetic pyrethroids possesses effective immediate and persistent activity against a large variety of arthropods, harmful both to human and animal health and to vegetal production (World Health Organization, Communicable Disease

\section{Springer Open}

(- The Author(s). 2021 Open Access This article is licensed under a Creative Commons Attribution 4.0 International License, which permits use, sharing, adaptation, distribution and reproduction in any medium or format, as long as you give appropriate credit to the original author(s) and the source, provide a link to the Creative Commons licence, and indicate if changes were made. The images or other third party material in this article are included in the article's Creative Commons licence, unless indicated otherwise in a credit line to the material. If material is not included in the article's Creative Commons licence and your intended use is not permitted by statutory regulation or exceeds the permitted use, you will need to obtain permission directly from the copyright holder. To view a copy of this licence, visit http://creativecommons.org/licenses/by/4.0/. 
Control, Prevention and Eradication, WHO Pesticide Evaluation Scheme, Protection of the Human Environment Programme on Chemical Safety, 2005). It is used for pest control to varieties of crops and in households. Researches have revealed that it is moderately toxic to mammals and highly toxic to fish and other aquatic invertebrates as well as bees (Anadon et al., 2006; Ratnasooriya et al., 2003). It has been reported that the aquatic organisms are highly vulnerable to pesticides contamination as run-offs from farms and industries end up in water bodies (Botelho, Santos, \& Oliveira, 2009; Nnamonu et al., 2018). Some substantial hazard in the environment occurs due to pesticides uptake and accumulation in the food chain (Somdare, 2015).

Toxically LCT forms a high level of free radicals, which induce oxidative stress. Exposure to toxic chemicals and environmental pollutants damage the histoarchitecture of gonads (Nnamonu, Mgbenka, \& Mbegbu, 2019). Gonads are highly susceptible to oxidative stress because their plasma membranes contain high concentration of polyunsaturated fatty acids (Alvarez \& Storey, 1995; Nnamonu et al., 2019), and their cytoplasm contains low concentrations of scavenging enzymes (De Lamirande \& Gagnon, 1995; Nnamonu et al., 2019).

Possible alterations and damages caused by LCT to the fish gonads will consequently result to a high level of infertility. If this happens, it will become a setback to the efforts been made by the governments toward ensuring food security especially in developing countries. In view of the foregoing, the present study was designed to evaluate oxidative stress and gonad histoarchitecture toxicity of LCT in C. gariepinus.

\section{Methods}

\section{Procurement of experimental fish}

A total of 120 C. gariepinus 16 to $40 \mathrm{~cm} \mathrm{SL}$ and 200 to 250 bodyweights were procured from Freedom Fisheries Ltd., University Market Road, Nsukka, Enugu State, Nigeria, and immediately transported to the Fisheries Wet Laboratory, Department of Zoology, and Environmental Biology, University of Nigeria, Nsukka. The fishes were disinfected with $0.05 \%$ potassium permanganate (KMnO4) for 2 min to avoid any dermal infections, later acclimatized for 2 weeks in plastic tanks of 300 liter (L) capacity. They were fed daily with food (Coppens commercial feed) containing $40 \%$ crude protein. Food, fecal matter, and other waste materials were siphoned off and water changed daily to reduce ammonia content in the water. Dead fishes were also removed with forceps to avoid possible deterioration of the water quality. During acclimatization, the water was changed after $48 \mathrm{~h}$ with well aerated tap water.

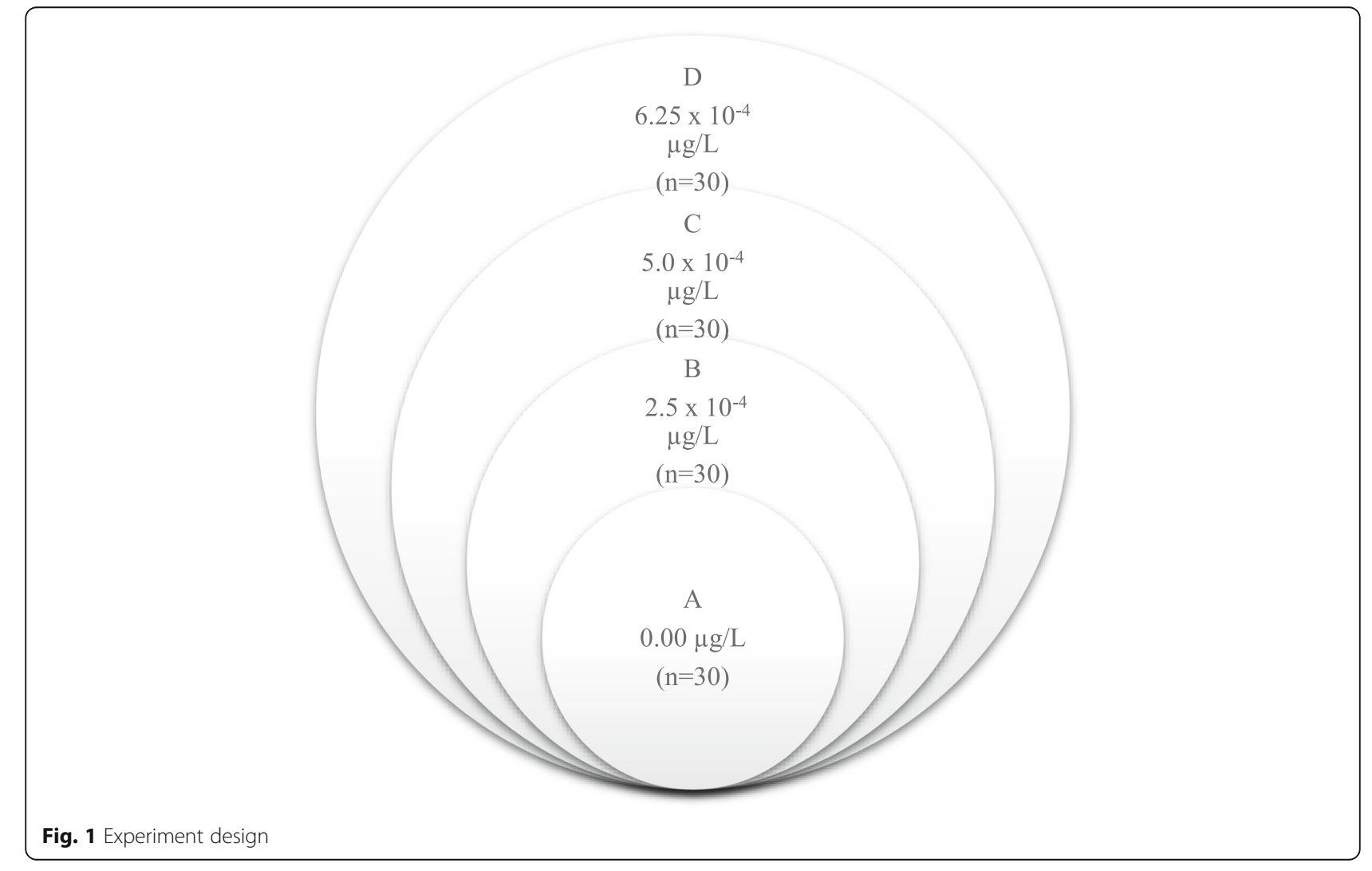




\section{Procurement of the test compound}

A commercial formulation of lambda-cyhalothrin (600 $\mathrm{gl}^{-1}$ ) with batch number 160227 marked by Amanik Agro Investment Limited Lagos, Nigeria, was purchased at Ogige Local Market Nsukka, Enugu State, Nigeria.

\section{Experimental design for sublethal exposure}

The experiment consisted of 120 fish assigned into four treatments of $0.00,2.5 \times 10^{-4} \mu \mathrm{g} / \mathrm{L}, 5.0 \times 10^{-4} \mu \mathrm{g} / \mathrm{L}$, and $6.25 \times 10^{-4} \mu \mathrm{g} / \mathrm{L}(\mathrm{A}-\mathrm{D})$, each treatment consisted of 30 fishes with three replicates (10 fishes per replicate) (Fig. 1). Each tank contained $10 \mathrm{~L}$ dechlorinated tap water with 10 fishes. Fish maintained in dechlorinated tap water served as the control treatment (A) while the three other treatments were exposed to water containing $2.5 \times$ $10^{-4} \mu \mathrm{g} / \mathrm{L}(\mathrm{B}), 5.0 \times 10^{-4} \mu \mathrm{g} / \mathrm{L}(\mathrm{C})$, and $6.25 \times 10^{-4} \mu \mathrm{g} / \mathrm{L}$ (D) of LCT corresponding to $1 / 20,1 / 10$, and $1 / 5$ of the 96 $\mathrm{h} \mathrm{LC}_{50}$ value that were determined after the acute toxicity assay. The exposure lasted for a period of 28 days during which the fish were fed with small quantity of feed approximately $1 \%$ of total body weight about an hour before the test solution were renewed daily. The feeding was to avoid catabolism and subsequent mortality. On each sampling day $(7,14,21$, and 28$)$, three to five fishes from each of the treatment groups including the control were sacrificed after anesthetizing with tricaine methanessulfonate (MS 222) to minimize stress. Blood samples were collected (through caudal alteration) for antioxidant enzyme test while gonads were harvested for histological studies. After the end of the sublethal exposure, the remaining fish in each of the concentrations were withdrawn from the exposure of the chemical and were placed in chemical-free water after which further observation were made after 7 days of the withdrawal.

\section{Lipid peroxidation}

LPO were examined by measuring malondialdehyde (MDA) formation as described by Sharma and Krishnamurti (1968) method. The MDA activity was expressed as nmol/protein after calculating with:

$$
L P O=\frac{O D \times 1000}{156 \times m g \text { protein }}
$$

Table 1 Effects of lambda-cyhalothrin on oxidative stress biomarkers

\begin{tabular}{|c|c|c|c|c|c|c|c|}
\hline \multirow[t]{2}{*}{ Parameter } & \multirow{2}{*}{$\begin{array}{l}\text { Concentration } \\
(\mu \mathrm{g} / \mathrm{L})\end{array}$} & \multicolumn{5}{|l|}{ Duration (days) } & \multirow{2}{*}{$\begin{array}{l}7 \text { days } \\
\text { recovery }\end{array}$} \\
\hline & & 1 & 7 & 14 & 21 & 28 & \\
\hline \multirow[t]{4}{*}{ CAT (u/mg protein) } & Control & $1.16 \pm 0.02^{\mathrm{a} 1}$ & $1.15 \pm 0.06^{\mathrm{a} 1}$ & $1.17 \pm 0.01^{\mathrm{a} 1}$ & $1.16 \pm 0.03^{\mathrm{a} 1}$ & $1.19 \pm 0.01^{\mathrm{a} 1}$ & $1.18 \pm 0.01^{\mathrm{a} 1}$ \\
\hline & $2.5 \times 10^{-4}$ & $1.17 \pm 0.01^{\mathrm{d} 1}$ & $1.26 \pm 0.01^{\mathrm{d} 12}$ & $1.60 \pm 0.03^{c 2}$ & $2.25 \pm 0.03^{\mathrm{b} 2}$ & $2.57 \pm 0.10^{\mathrm{a} 2}$ & $1.50 \pm 0.07^{c 1}$ \\
\hline & $5.0 \times 10^{-4}$ & $1.30 \pm 0.02^{\mathrm{b} 2}$ & $1.26 \pm 0.02^{b 12}$ & $1.67 \pm 0.02^{\mathrm{b} 2}$ & $2.67 \pm 0.36^{\mathrm{a} 2}$ & $2.89 \pm 0.18^{\mathrm{a} 23}$ & $1.64 \pm 0.10^{\mathrm{b} 1}$ \\
\hline & $6.25 \times 10^{-4}$ & $1.35 \pm 0.05^{\mathrm{d} 2}$ & $1.33 \pm 0.02^{\mathrm{d} 2}$ & $1.97 \pm 0.08^{c 3}$ & $2.79 \pm 0.32^{a b 2}$ & $3.05 \pm 0.15^{\mathrm{a} 3}$ & $2.42 \pm 0.28^{b c 2}$ \\
\hline \multirow[t]{4}{*}{ SOD (u/mg protein) } & Control & $10.90 \pm 0.04^{\mathrm{a} 1}$ & $10.92 \pm 0.07^{\mathrm{a} 1}$ & $10.62 \pm 0.06^{\mathrm{a} 1}$ & $10.79 \pm 0.20^{\mathrm{a} 1}$ & $10.88 \pm 0.07^{\mathrm{a} 1}$ & $10.68 \pm 0.19^{\mathrm{a} 1}$ \\
\hline & $2.5 \times 10^{-4}$ & $10.65 \pm 0.12^{b 1}$ & $10.82 \pm 0.04^{\mathrm{b} 1}$ & $10.89 \pm 0.03^{\mathrm{b} 2}$ & $11.28 \pm 0.10^{\mathrm{a} 1}$ & $11.41 \pm 0.13^{\mathrm{a} 2}$ & $10.69 \pm 0.13^{\mathrm{b} 1}$ \\
\hline & $5.0 \times 10^{-4}$ & $10.68 \pm 0.11^{b 1}$ & $10.76 \pm 0.16^{\mathrm{b} 1}$ & $10.88 \pm 0.03^{b 2}$ & $11.41 \pm 0.12^{\mathrm{a} 1}$ & $11.51 \pm 0.16^{\mathrm{a} 2}$ & $10.91 \pm 0.06^{\mathrm{b} 1}$ \\
\hline & $6.25 \times 10^{-4}$ & $10.85 \pm 0.07^{b 1}$ & $10.90 \pm 0.02^{\mathrm{b} 1}$ & $10.90 \pm 0.07^{\mathrm{b} 2}$ & $11.21 \pm 0.47^{\mathrm{ab} 1}$ & $11.75 \pm 0.16^{\mathrm{a} 2}$ & $10.97 \pm 0.07^{\mathrm{b} 1}$ \\
\hline \multirow[t]{4}{*}{ MDA (u/mg protein) } & Control & $2.75 \pm 0.12^{\mathrm{a} 1}$ & $2.92 \pm 0.19^{\mathrm{a} 1}$ & $2.49 \pm 0.47^{\mathrm{a} 1}$ & $2.54 \pm 0.25^{\mathrm{a} 1}$ & $2.39 \pm 0.06^{\mathrm{a} 1}$ & $2.33 \pm 0.06^{\mathrm{a} 1}$ \\
\hline & $2.5 \times 10^{-4}$ & $2.51 \pm 0.15^{\mathrm{c} 1}$ & $2.63 \pm 0.16^{\mathrm{c} 1}$ & $2.82 \pm 0.14^{\mathrm{bc} 1}$ & $3.19 \pm 0.13^{b 12}$ & $4.09 \pm 0.05^{\mathrm{a} 2}$ & $2.73 \pm 0.03^{c 2}$ \\
\hline & $5.0 \times 10^{-4}$ & $2.91 \pm 0.13^{\mathrm{bc} 1}$ & $2.53 \pm 0.21^{\mathrm{c} 1}$ & $2.90 \pm 0.07^{\mathrm{bc} 1}$ & $3.38 \pm 0.40^{\mathrm{b} 12}$ & $4.26 \pm 0.23^{\mathrm{a} 2}$ & $2.78 \pm 0.03^{b c 2}$ \\
\hline & $6.25 \times 10^{-4}$ & $3.10 \pm 0.42^{b 1}$ & $3.30 \pm 0.35^{b 1}$ & $2.90 \pm 0.12^{\mathrm{b} 1}$ & $3.74 \pm 0.28^{\mathrm{a} 2}$ & $4.33 \pm 0.15^{\mathrm{a} 2}$ & $2.98 \pm 0.02^{b 3}$ \\
\hline \multirow[t]{4}{*}{ GPx (u/mg protein) } & Control & $10.92 \pm 0.58^{\mathrm{a} 1}$ & $10.05 \pm 0.29^{\mathrm{a} 1}$ & $11.19 \pm 0.49^{\mathrm{a} 1}$ & $11.04 \pm 0.36^{\mathrm{a} 1}$ & $10.80 \pm 0.25^{\mathrm{a} 1}$ & $10.71 \pm 0.24^{\mathrm{a} 1}$ \\
\hline & $2.5 \times 10^{-4}$ & $12.64 \pm 0.76^{b c 12}$ & $11.49 \pm 0.76^{\mathrm{c} 12}$ & $14.08 \pm 0.29^{\mathrm{ab} 2}$ & $14.23 \pm 0.25^{\mathrm{ab} 2}$ & $15.01 \pm 0.26^{\mathrm{a} 2}$ & $11.21 \pm 0.50^{c 1}$ \\
\hline & $5.0 \times 10^{-4}$ & $12.35 \pm 1.04^{b c 12}$ & $13.50 \pm 0.29^{a b 2}$ & $14.08 \pm 0.29^{\mathrm{a} 2}$ & $14.69 \pm 0.43^{\mathrm{a} 2}$ & $15.17 \pm 0.26^{\mathrm{a} 2}$ & $11.48 \pm 0.57^{\mathrm{c} 1}$ \\
\hline & $6.25 \times 10^{-4}$ & $13.50 \pm 0.29^{b c d} 2$ & $12.93 \pm 0.99^{\mathrm{cd} 2}$ & $14.36 \pm 0.29^{\mathrm{abc} 2}$ & $14.84 \pm 0.19^{\mathrm{ab} 2}$ & $15.50 \pm 0.50^{\mathrm{a} 2}$ & $11.78 \pm 0.57^{\mathrm{d} 1}$ \\
\hline \multirow[t]{4}{*}{ GR (u/mg protein) } & Control & $2.81 \pm 0.16^{\mathrm{a} 1}$ & $2.75 \pm 0.20^{\mathrm{a} 1}$ & $2.55 \pm 0.21^{\mathrm{a} 1}$ & $2.57 \pm 0.06^{\mathrm{a} 1}$ & $2.71 \pm 0.05^{\mathrm{a} 1}$ & $2.72 \pm 0.07^{\mathrm{a} 1}$ \\
\hline & $2.5 \times 10^{-4}$ & $2.83 \pm 0.18^{b 1}$ & $2.70 \pm 0.31^{b 1}$ & $2.93 \pm 0.20^{b 1}$ & $3.13 \pm 0.14^{b 2}$ & $3.98 \pm 0.19^{\mathrm{a} 2}$ & $2.50 \pm 0.20^{b 1}$ \\
\hline & $5.0 \times 10^{-4}$ & $2.88 \pm 0.17^{\mathrm{b} 1}$ & $2.91 \pm 0.21^{b 1}$ & $3.00 \pm 0.17^{b 1}$ & $3.26 \pm 0.14^{b 2}$ & $4.13 \pm 0.21^{\mathrm{a} 2}$ & $2.71 \pm 0.15^{\mathrm{b} 1}$ \\
\hline & $6.25 \times 10^{-4}$ & $2.91 \pm 0.15^{\mathrm{b} 1}$ & $3.00 \pm 0.15^{b 1}$ & $3.13 \pm 0.18^{b 1}$ & $3.35 \pm 0.17^{b 2}$ & $4.24 \pm 0.24^{\mathrm{a} 2}$ & $2.78 \pm 0.12^{b 1}$ \\
\hline
\end{tabular}

Values as mean \pm S.E. For each parameter, values with different alphabet superscript across a row were significantly different; and values with different numeric superscript down a column were significantly different $(p<0.05)$ 


\section{Catalase activity}

Catalase activity was examined as described by Acbi (1984) method. The CAT activity was expressed as U/ mg protein after calculating with:

$$
C A T=\frac{\Delta O D \text { of } \text { Test } \times \text { total volume } \times 1000}{43.6 \times 0.05 m l \text { sample } \times m g \text { protein }}
$$

\section{Superoxide dismutase}

SOD activity was determined by measuring the inhibition of autoxidation of adrenaline at $\mathrm{pH} 10.2$ at $30{ }^{\circ} \mathrm{C}$ as described by Misra and Fridovich (1972) method.
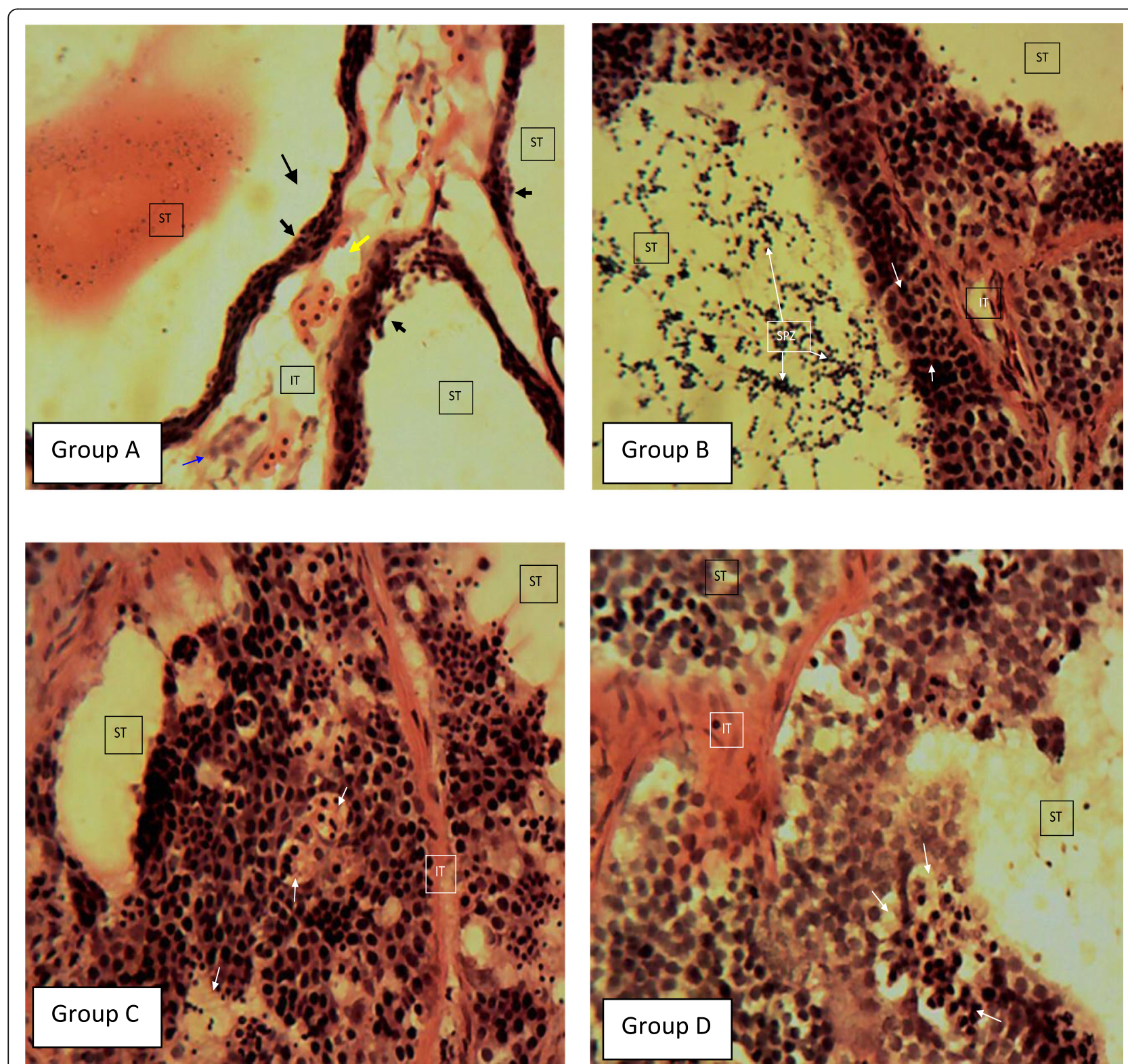

Fig. 2 Histopathology of the testes of C. gariepinus exposed to different concentrations of lambda-cyhalothrin after 1 day. Group A (control), B $\left(2.5 \times 10^{-4} \mu \mathrm{g} / \mathrm{L}\right), C\left(5.0 \times 10^{-4} \mu \mathrm{g} / \mathrm{L}\right)$, and D $\left(6.25 \times 10^{-4} \mu \mathrm{g} / \mathrm{L}\right)$ (testicular interstitium (IT), spermatozoa (SPZ), seminiferous tubules (ST). H\&E $\left.\times 400\right)$ 


\section{Glutathione reductase}

GR was estimated by measuring the rate of conversion of NADPH using the method of Tayarani, Cloez, and Bourne (1989). Specific activity was expressed as $\mu \mathrm{mol}$ NADPH oxidized $\mathrm{min}^{-1} \mathrm{mg}^{-1}$ protein, taking motor extinction coefficient of NADPH as $6300 \mathrm{~m}^{-1} \mathrm{~cm}^{-1}$ after calculating with:

$$
G R=\frac{\Delta O D \text { change } / \min \times 6.3}{m g \text { of protein }} \times 100
$$

Histological study of the gonad

At days 1, 14, and 28, fish were sampled from control and each treatment. The Gonad (testis and ovary) were harvested through dissection, preserved in $10 \%$ phosphate-buffered formalin for $24 \mathrm{~h}$, dehydrated by a series of graded concentration of ethanol solution, embedded in paraffin, and sectioned at $5 \mu \mathrm{m}$ thick using microtila. Tissue sections were routinely processed and stained with hematoxylin and eosin (H\&E), examined by binocular microscopy while the photomicrographs were captured using motic camera (Robert, 2001).
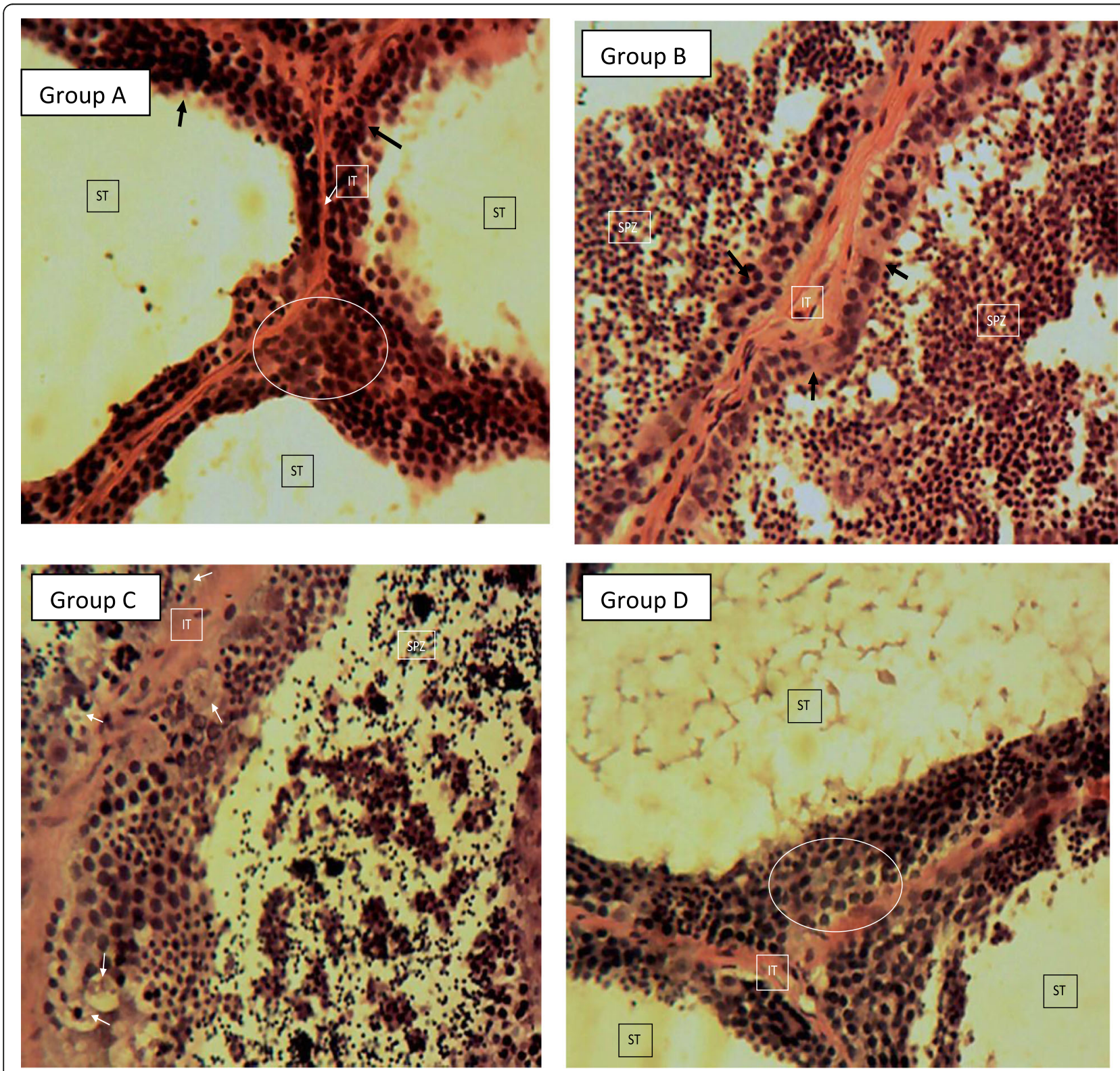

Fig. 3 Histopathology of the testes of C. gariepinus exposed to different concentration of lambda-cyhalothrin on 14 days. Group A (control) active spermatogenic stage (white circle) and abundant spermatogenic cells (black arrows), B $\left(2.5 \times 10^{-4} \mu \mathrm{g} / \mathrm{L}\right), \mathrm{C}\left(5.0 \times 10^{-4} \mu \mathrm{g} / \mathrm{L}\right)$, and D (6.25 $\times$ $10^{-4} \mathrm{\mu g} / \mathrm{L}$ ) (seminiferous tubule (ST), spermatocyst (white circle), testicular interstitium (IT), and spermatozoa (SPZ); H\&E $\times 400$ ) 


\section{Statistical analysis}

Data were analyzed using Statistical Packages for Social Sciences (SPSS) version 20.0 (IBM Corp, Armonk, USA) and Statplus v5.9.8 (AnalystSoft Inc., Walnut, Canada). Two-way analysis of variance (ANOVA) was used to compare concentration of lambda-cyhalothrin and duration of exposure dependent effects. The means were partitioned using DMRT (Duncan multiple range test). Level of significance was set at $p<0.05$.

\section{Results}

Effects of different concentration of lambda-cyhalothrin on antioxidant enzymes in C. gariepinus

The effects of different concentration of lambdacyhalothrin on antioxidant enzymes in C. gariepinus were shown in Table 1. There were an established dose and duration dependent significant effects in parameters. On day 7, SOD, MDA, and GR showed no significant difference $(p>0.05)$, CAT and GPx significantly increased $(p<0.05)$ in all treatments compared with
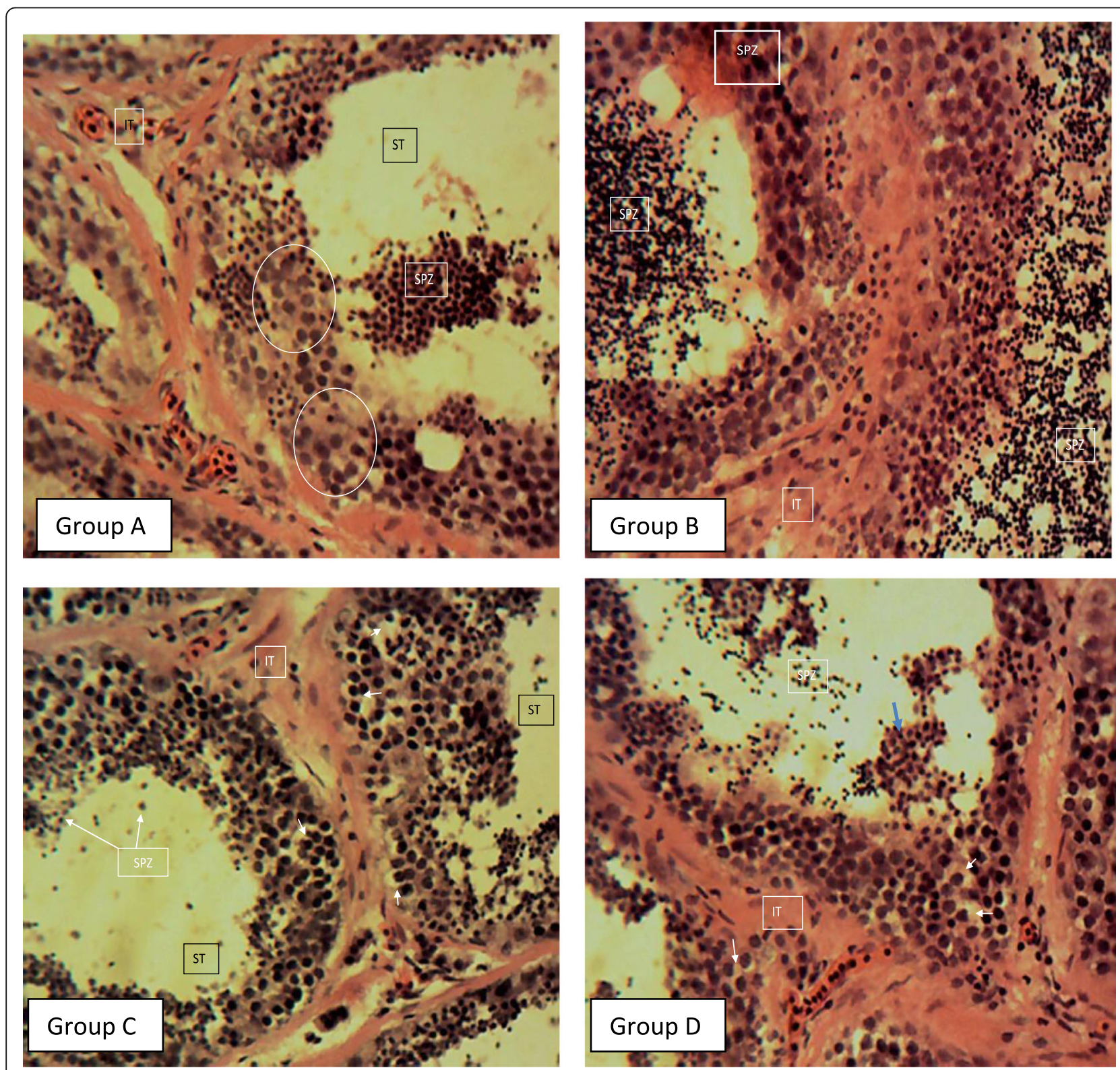

Fig. 4 Histopathology of the testes of C. gariepinus exposed to different concentration of lambda-cyhalothrin on day 28. Group A (control), B (2.5 $\left.\times 10^{-4} \mathrm{\mu g} / \mathrm{L}\right), C\left(5.0 \times 10^{-4} \mathrm{\mu g} / \mathrm{L}\right)$, and $D\left(6.25 \times 10^{-4} \mu \mathrm{g} / \mathrm{L}\right)$ (seminiferous tubule (ST), spermatocyst (white circle), testicular interstitium (IT), and spermatozoa (SPZ) H\&E $\times 400$ ) 
control down the column. On day 14, CAT, MDA, and GR showed no significant difference $(p>0.05)$, while SOD and GPx significantly increased $(p<0.05)$ compared with control down the column. Whereas day 21 recorded significant increase $(p<0.05)$ in all parameters except SOD, there was a significant increase in all parameters tested compared with control down the column at day 28 .

All the biomarkers of peroxidation increased significantly on day 28 across the row when compared to day 1 for groups exposed to $2.5 \times 10^{-4}, 5.0 \times 10^{-4}$, and 6.25 $\times 10^{-4} \mu \mathrm{g} / \mathrm{L}$ lambda-cyhalothrin $(p<0.05)$.

The significant increase $(p<0.05)$ in SOD, MDA, GPx, and GR levels returned to normal after 7 days of depuration but the CAT level did not return to normal.
Histopathology of the testes of C. gariepinus exposed to different concentration of lambda-cyhalothrin after 1 day The photomicrographs of testes harvested on day 1 (Fig. 2) displayed some destructive effects in testes histoarchitecture of the treated animals. Group B recorded variable sized and shaped seminiferous tubules lined by abundant spermatogenic cells was observed. Early stages of the spermiation stage and spermatogenic stage were observed in this section. The spermiation stages were exhibited by the presence of free spermatozoa (SPZ) in the lumen of the seminiferous tubules (ST) while the active spermatogenic stages are exhibited by the presence of spermatocysts (white arrow). Histological changes observed in group B also occurred in group C. Multiple clusters of necrotic spermatogenic cells with nuclear pyknosis and cytoplasmic swellings were observed in group D (Fig. 2).
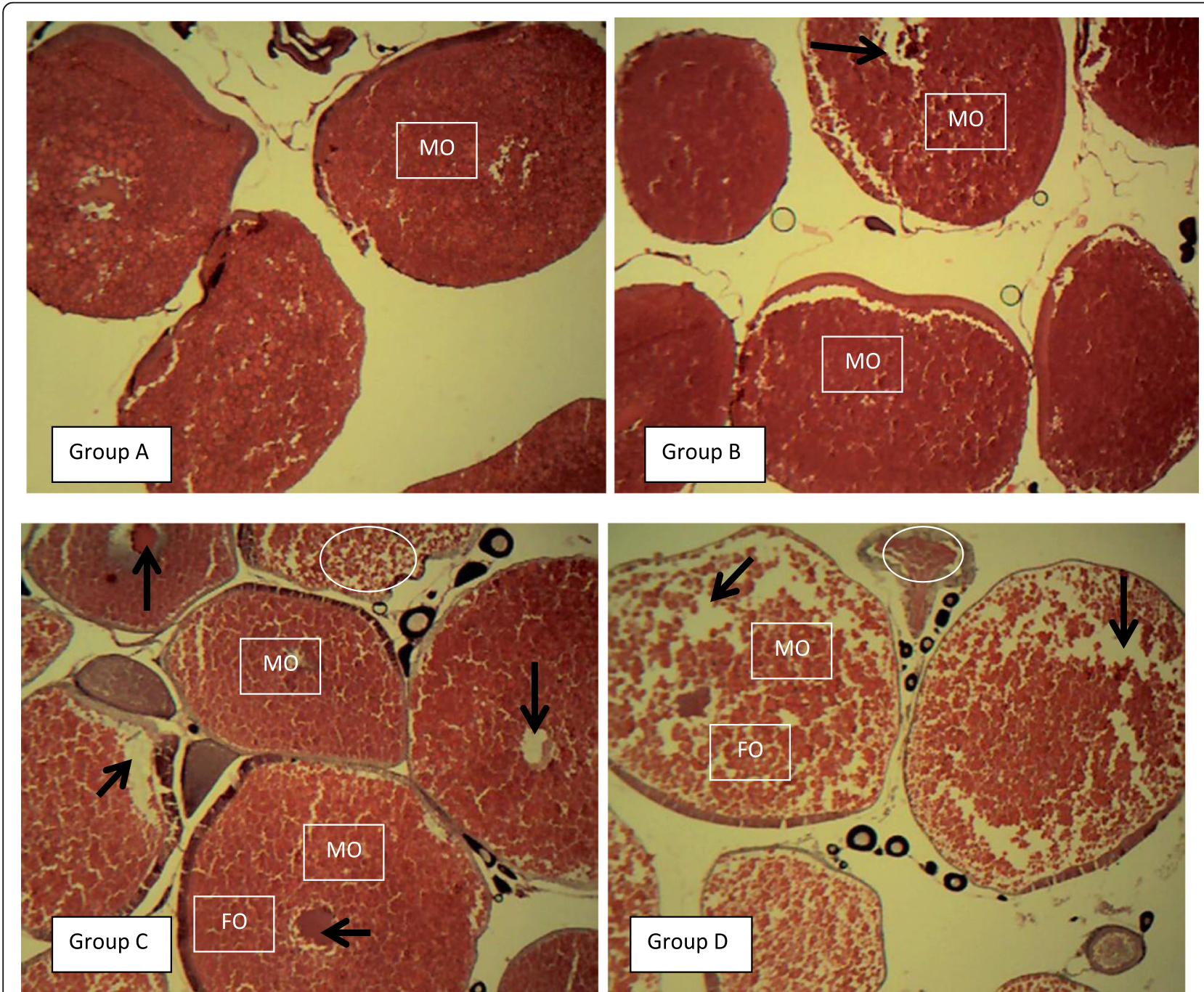

Fig. 5 Histopathology of the ovary of C. gariepinus exposed to different concentration of lambda-cyhalothrin after day 1. Group A (control), B (2.5 $\left.\times 10^{-4} \mu \mathrm{g} / \mathrm{L}\right), C\left(5.0 \times 10^{-4} \mu \mathrm{g} / \mathrm{L}\right)$, and $\mathrm{D}\left(8.25 \times 10^{-4} \mathrm{\mu g} / \mathrm{L}\right)(\mathrm{MO}$, mature oocyte; FO, flabby oocyte; white circle, degenerative ovarian changes; black arrow, vacuolation; H\&E; Mag. $\times 400)$ 

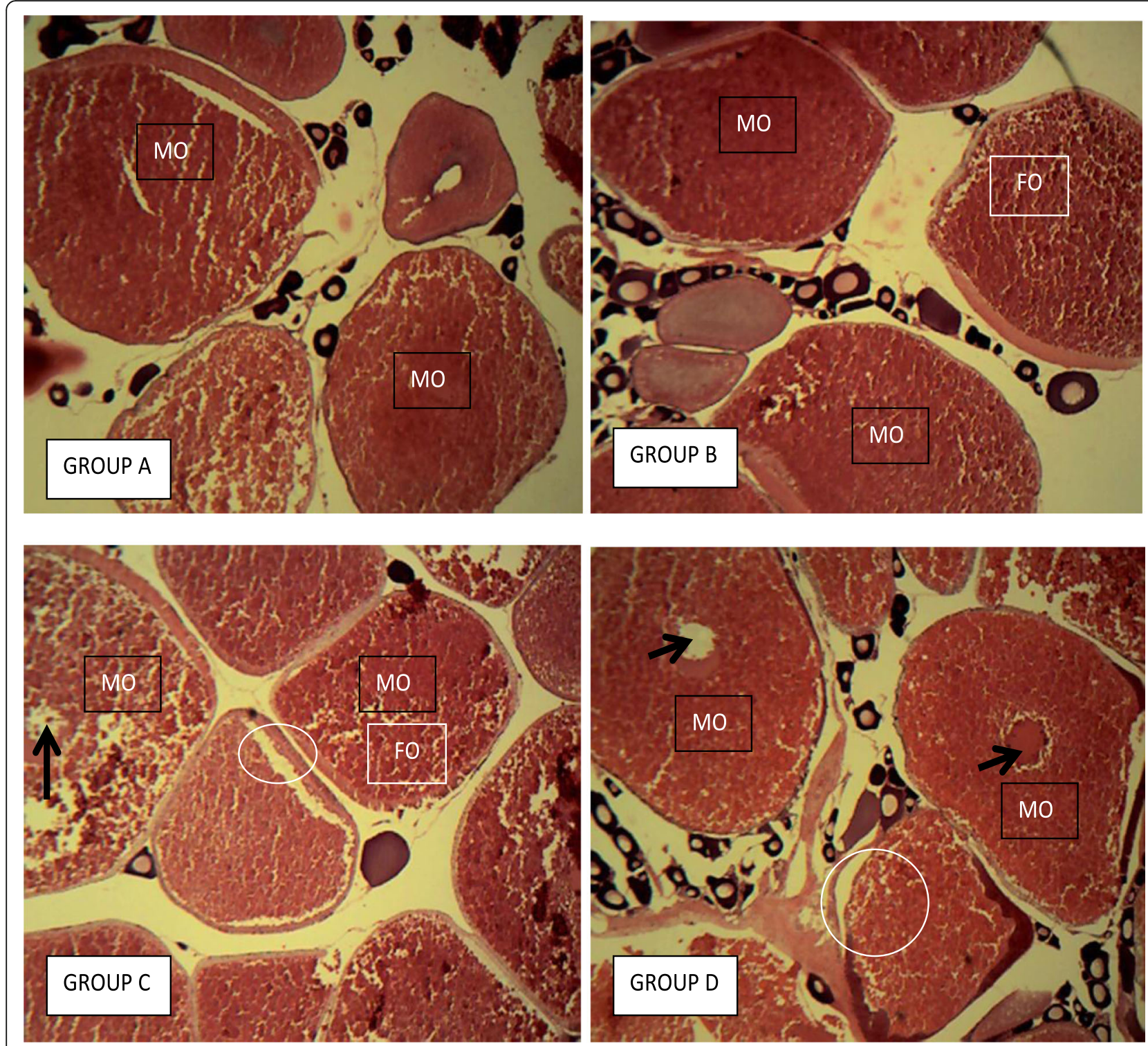

Fig. 6 Histopathology of the ovary of C. gariepinus exposed to different concentration of lambda-cyhalothrin on day 14. Group A (control), B (2.5 $\left.\times 10^{-4} \mathrm{\mu g} / \mathrm{L}\right), \mathrm{C}\left(5.0 \times 10^{-4} \mathrm{\mu g} / \mathrm{L}\right)$, and $\mathrm{D}\left(8.25 \times 10^{-4} \mathrm{\mu g} / \mathrm{L}\right)(\mathrm{MO}$, mature oocyte; FO, flabby oocyte; white circle, degenerative ovarian changes; black arrow, vacuolation; H\&E; Mag. $\times$ 400)

Group A (control) showed the normal histomorphology structure of the fish testes with large round to irregular shaped seminiferous tubules. The tubules were lined by sparsely accumulated spermatogenic cells (spermatogonia, spermatocytes, and/or spermatids) and surrounded by indistinct cytoplasmic arms of the Sertoli cells. The seminiferous tubules are separated by testicular interstitium which is composed of the interstitial cells and blood vessels. The predominant maturation phase observed in this section is the spermiation stage (Fig. 2).
Histopathology of the testes of C. gariepinus exposed to different concentration of lambda-cyhalothrin on 14 days The photomicrographs of testes harvested on day 14 (Fig. 3) displayed severe levels of destructive effects in testes histoarchitecture of the treated animals compared to day 1 . Whereas group B showed normal histomorphology of the fish testes with variable sized and shaped seminiferous tubules lined by spermatogenic cells, multiple clusters of necrotic spermatogenic cells (white arrow) with evidence of nuclear pyknosis and swelling of cytoplasm were observed in 

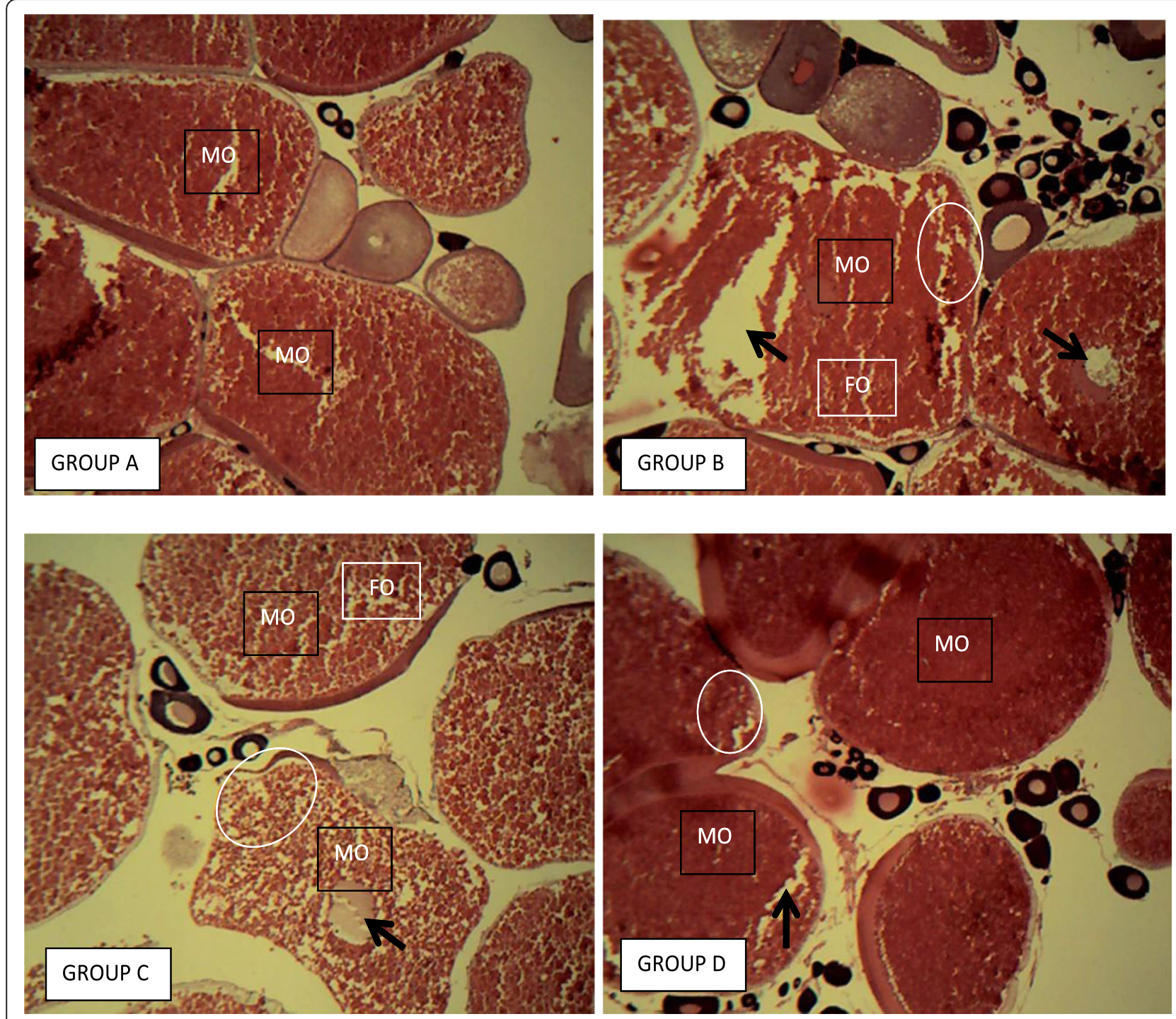

Fig. 7 Histopathology of the ovary of C. gariepinus exposed to different concentration of lambda-cyhalothrin on day 28. Group A (control), B (2.5 $\left.\times 10^{-4} \mu \mathrm{g} / \mathrm{L}\right), C\left(5.0 \times 10^{-4} \mu \mathrm{g} / \mathrm{L}\right)$, and D $\left(8.25 \times 10^{-4} \mu \mathrm{g} / \mathrm{L}\right)(\mathrm{MO}$, mature oocyte; FO, flabby oocyte; white circle, degenerative ovarian changes; black arrow, vacuolation; H\&E; Mag. $\times 400)$

the group $\mathrm{C}$ while the active non-deformed spermatocyst appeared in the group D.

Group A (control) showed no recognizable alteration in the histomorphology of the fish testes. The predominant maturation stage present in the control group is the active spermatogenic stage which is exhibited by the presence of spermatocysts.

Histopathology of the testes of C. gariepinus exposed to different concentration of lambda-cyhalothrin on day 28 The photomicrographs of testes harvested on day 28 (Fig. 4) displayed severe levels of alterations in testes histoarchitecture of the treated animals. Groups B and C showed similar effects. They displayed multiple clusters of degenerative spermatogenic cells (white arrow) with cytoplasmic swellings, while in group D, multiple clusters of necrotic spermatogenic cytoplasmic swelling and sloughed epithelial cells were observed.

Group A (control) showed normal histomorphology of the fish testes with variable sized and shaped seminiferous tubules lined by active spermatogenic cells (white circle). Two stages of maturation: the spermiation stage and spermatogenic stage were observed (Fig. 4).

Histopathology of the ovary of C. gariepinus exposed to different concentration of lambda-cyhalothrin after day 1 The photomicrographs of ovary harvested on day 1 are displayed in Fig. 5. Group A (control) showed normal ovarian histomorphology of the fish with predominance of large matured oocytes (type IV) and 
granular cytoplasm bound by vitelline membrane of variable thicknesses. Group B showed normal ovarian histomorphology, degenerative ovarian, and mature oocytes bounded by vitelline membrane. Groups C and $\mathrm{D}$ showed degenerative ovarian changes, mature oocytes and flabby structures, and vacuolation oocytes, respectively.

\section{Histopathology of the ovary of C. gariepinus exposed to different concentration of lambda-cyhalothrin on day 14} The photomicrographs of ovary harvested on day 14 are displayed in Fig. 6. Group A showed normal ovarian histomorphology of the fish and a predominance of large mature oocytes (type IV) with granular cytoplasm bound by vitelline membrane of variable thicknesses (Fig. 6). Group B showed matured oocytes, flabby structures, and granulose cells that surround the secondary oocytes. Group C exhibited prominent degenerative ovarian changes, flabby structures, and matured oocytes while more pronounced vacuolation, degenerative ovarian changes, matured oocytes, and granulose cells were observed in group D (Fig. 6).

\section{Histopathology of the ovary of C. gariepinus exposed to different concentration of lambda-cyhalothrin on day 28} The photomicrographs of ovary harvested on day 28 are displayed in Fig. 7. Group A displayed the normal ovarian histomorphology of the fish, predominant large mature oocytes (type IV) with granular cytoplasm bound by vitelline membrane of variable thicknesses. Groups B and $\mathrm{C}$ showed more pronounced degenerative ovarian, matured oocytes, flabby structured, and vacuolation oocytes, while nuclear pyknosis, mature oocytes, degenerative ovarian changes, flabby, and vacuolation oocytes were noted in group D (Fig. 7).

\section{Discussion}

The present study demonstrated that C. gariepinus exposed to lambda-cyhalothrin showed concentration and duration dependent on significant increases $(p<0.05)$ in radical activities. Oxidative stress is another mechanism for toxicity leading to cell death and disturbance of the physiological processes in fish (Banaee, 2013). It is related to reactive oxygen species production and can occur when the antioxidant and detoxifying systems are deficient not able to neutralize the active intermediates that are produced by xenobiotics and their metabolites. Changes in the levels of antioxidant enzyme activities could be used as biomarkers in different aquatic organisms (Orbea, Ortiz-Zarragoitia, Sole', Porte, \& Cajaravile, 2002).

The higher LCT concentration showed a marked increase in MDA, and this could be as a result of its free radical synthesis ability which physiologically induces stress. The finding consonants with Nnadi, 2016. In fish, SOD and CAT constitute the first line of defense against oxidative stress. Whereas SOD catalyzes the dismutation of superoxide into hydrogen peroxide and oxygen, CAT catalyzes the decomposition of hydrogen peroxide into water and oxygen (Banaee, 2013). The present research demonstrated that CAT and SOD antioxidant activities increased significantly $(p<0.05)$ in fish exposed to different concentrations of lambda-cyhalothrin. This depicts that LCT caused production of harmful molecules called free radicals beyond the protective capacity of the antioxidant defenses. Somdare (2015) and Nnadi (2016) made similar findings. Glutathione peroxidase (GPx) and glutathione reductase (GR) are groups of cytosolic detoxifying enzymes found in different tissues, which defend cells against the mutagenic, carcinogenic, and toxic impacts of various pollutants helping in prevention of lipid peroxidation and suppressing apoptosis (Banaee, 2013). The significant increase $(p<0.05)$ in GPx and GR exposed to LCT in this study indicated that GPx and GR fluctuation activities were influenced. This finding conforms with Kanchan, Chaki, and Misro (2002).

The present study had also demonstrated that the significant increase $(p<0.05)$ in SOD, MDA, GPx, and GR levels returned to normal after 7 days of depuration but the significant increase $(p<0.05)$ CAT level did not return to normal. We therefore report that the oxidative stress effect of LCT in C. gariepinus is severe considering the fact that CAT is a major antioxidant enzyme in fish.

The testes of C. gariepinus exposed to lambdacyhalothrin-graded concentration in this study showed necrotic conditions in the spermatogenic cells with nuclear pyknosis and cytoplasmic swelling. The observed necrosis (unprogrammed cell death) of various stages of the germ cell within the spermatogenic cycle suggested that the germ cell maturation was distorted during the process of spermatogenesis with subsequent degeneration. This could be that LCT contained estrogenic properties which could cause disorder in the testes of the fish. The findings were consistent with the report of Jaensson, Scott, Moore, Kylin, and Olsén (2007).

The ovary harvested from LCT-treated C. gariepinus showed in this study showed concentration and duration-based effects. Ovarian damages observed in the female gonad cursed a trend of increased frequency of ovaries with vacuolations, flabby oocytes, and degenerated ovary changes. Histopathological investigation indicated that the normal abnormalities in the female gonads may have contributed to the deformities in the egg structures and viability. Gonad lesions observed could have resulted in the degenerative ovarian changes, flabby oocytes, and vacuolation in the oocytes of C. gariepinus exposed to LCT. This agreed with the report of Kausik, Bodhisatwa, and Salma (2015). 


\section{Conclusion}

The present study has demonstrated that lambdacyhalothrin affected various antioxidants activities and gonad functions of C. gariepinus. Specifically, the significant increase in CAT could not return to normal after 7 days of depuration. This simply implies that lambdacyhalothrin is toxic to C. gariepinus.

\section{Abbreviations}

LCT: Lambda-cyhalothrin; CAT: Catalase activity; GPx: Glutathione peroxidase; SOD: Superoxide dismutase; GR: Glutathione reductase; LPO: Lipid peroxidation; MDA: Malondialdehyde

\section{Acknowledgements}

Authors appreciate Professor Christopher Ndidiugwu Nwani of Department of Zoology and Environmental Biology, University of Nigeria, Nsukka, and the zoo attendants at the zoological garden, University of Nigeria, Nsukka, for their contributions during this study.

\section{Authors' contributions}

SUE provided all the materials used for this study. GEO, SUE, EIN, and COA designed this research. SUE, EIN, and $\mathrm{BCI}$ were responsible for the drug administration, feeding, and taking care of the experimental animals while GEO supervised these aspects. All authors handled the laboratory and statistical analysis. The manuscript was prepared by EIN while all authors edited it. The final version was read and approved by all authors.

\section{Funding}

This research was funded by Mr. Samuel Uchechukwu Ezenwosu. There was no external sponsorship.

\section{Availability of data and materials}

We declare that data generated from this study are readily available as well as information about material used.

\section{Ethics approval and consent to participate}

Ethical approval handling of experimental animals used in this research was in accordance with the recommendation of the Committee on Ethical Issues Concerning Animal Research Outside the Laboratory (Nisbet \& Paul, 2004). The University of Nigeria, Nsukka, Senate committee on Medical and Research ethics also gave their consent. All authors gave their consent to be part of this study and also participated fully during the study.

\section{Consent for publication}

Not applicable.

\section{Competing interests}

Authors declare that there is no conflict of interest among authors.

\section{Author details}

${ }^{1}$ Department of Biology, Federal College of Education, Eha-Amufu, Enugu State, Nigeria. ${ }^{2}$ Department of Zoology and Environmental Biology, University of Nigeria, Nsukka, Enugu State, Nigeria. ${ }^{3}$ Department of Applied Biology, Ebonyi State University, Abakaliki, Nigeria.

Received: 3 April 2020 Accepted: 15 December 2020

Published online: 07 January 2021

\section{References}

Acbi, H. (1984). Catalase in vitro. Enzymology, 105, 121-126.

Alvarez, J. G., \& Storey, B. T. (1995). Differential incorporation of fatty acids into and peroxidative loss of fatty acids from phospholipids of human spermatozoa. Molecular Reproduction and Development, 42(3), 334-346.

Anadon, A., Martinez, M., Martinez, M. A., Diaz, M. J., \& Martinez-Larranaga, M. R. (2006). Toxicokinetics of lambda-cyhalothrin in rats. Toxicology Letters, 165, $47-56$

Banaee, M. (2013). Physiological dysfunction in fish after insecticides exposure. In P. Stanislav Trdan (Ed.), Insecticides - Development of Safer and More Effective Technologies.
Botelho, R. G., Santos, J. B., \& Oliveira, T. A. (2009). Toxicidade aguda de herbicidas a Tilapia (Oreochnomis niloticus). Planta Daninha, 27, 621-626.

De Lamirande, E., \& Gagnon, C. (1995). Impact of reactive oxygen species on spermatozoa: A balancing act between beneficial and detrimental effects. Human Reproduction, 10(suppl 1), 15-21.

Jaensson, A., Scott, A. P., Moore, A., Kylin, H., \& Olsén, K. H. (2007). Effects of a pyrethroid pesticide on endocrine responses to female odours and reproductive behaviour in male parr of brown trout (Salmo trutta L.). Aquatic Toxicology, 81, 1-9.

Kanchan, U., Chaki, S. P., \& Misro, M. M. (2002). Evaluation of peroxidative stress and enzymatic antioxidant activity in the liver and kidney during pregnancy and lactation in rats. Health Population Perspective, 25(4), 177-185.

Kausik, M., Bodhisatwa, K., \& Salma, H. (2015). A review on the pyrethroid pesticides on fresh water behaviour and fish reproduction. Journal of Global Biosciences, 4, 2594-2598.

Lawrence, R. A., \& Burk, R. F. (1976). Glutathione peroxidase activity in selenium deficient rat liver. Biochemal and Biophysical Research Communications, 71, 952-958.

Ling, S., Yu-Bang, W., Hong, S., Chen, Y., Xia, H., Jian-Hua, Q., ... Xin-Ru, W. (2008). Effects of fenvalerate and cypermethrin on rat sperm motility patterns in vitro as measured by computer-assisted sperm analysis. Journal of Toxicology and Environmental Health (PartA), 71(5), 325-332.

Maton, S. M., Dodo, J. D., Nesla, R. A., \& Ali, A. Y. (2016). Environmental impact of pesticides usage on farmlands in Nigeria. International Journal of Innovative Research and Development, 5(4), 311-317.

Misra, P., \& Fridovich, I. (1972). The role of superoxide amion in the autooxidation of epinephrine and a simple assay for superoxide dismutase. Journal of Biological Chemistry, 247, 3170-3175.

Nisbet, I. C. T., \& Paul, E. (2004). Ehtical issues concerning animal research outside the laboratory. Institute for Laboratory and Animal Research Journal, 45(3), 375-377.

Nnadi, J.U. (2016). Effects of exposure of termex on morphological variations and oxidative stress parameters in juvenile Clarias gariepinus. Unpublished thesis submitted to the department of Zoology and environmental biology, University of Nigeria Nsukka.

Nnamonu, E. I., Mgbenka, B. O., \& Mbegbu, E. C. (2019). Fertility enhancing potency of omega-3 fatty acids in male rats. Brazilian Archives of Biology and Technology, 62, 1-8

Nnamonu, E. I., Nkitnam, E. E., Ugwu, F. J., Ejilibe, O. C., Ezenwosu, S. U., \& Ogbodo, G. U. (2018). Physicochemical assessment of vulnerability of the river Ebenyi in Eha-Amufu and Environs, Southeast Nigeria. Annual Research \& Review in Biology, 27(5), 1-9.

Orbea, A., Ortiz-Zarragoitia, M., Solé, M., Porte, C., \& Cajaravile, M. P. (2002). Antioxidant enzymes and peroxisomes proliferation in relation to contaminant body burdens of PAHs and PCBs in bivalve mollusc, crab, and fish from the Urdaibai and Plentzia estuaries (Bay of Biscay). Aquatic Toxicology, 58, 75-98.

Ratnasooriya, W. D., Ratnayake, S. S., \& Jayatunga, Y. N. (2003). Effects of Icon, a pyrethroid insecticide on early pregnancy of rats. Human and Experimental Toxicology, 22, 523-533.

Robert, R. J. (2001). Fish pathology: 3rd. London: Bailliere Tindall.

Sharma, S. K., \& Krishna-murti, C. R. (1968). Production of lipid peroxides by brain. Journal of Neurochemistry, 17, 144-147.

Somdare, P. O. (2015). Oxidative stress biomarkers, haematological parameters and histopathological changes in the African catfish, Clarias gariepinus exposed to an organophosphate pesticide. Fenthion: Unpublished Project Submitted to the Department of Zoology and Environmental Biology, University of Nigeria, Nsukka.

Tayarani, I., Cloez, M., \& Bourne, J. M. (1989). Antioxidant enzymes and related trace elements in aging brain capillaries and choroid plexus. Journal of Neurochemistry, 53, 817-824.

World Health Organization, Communicable Disease Control, Prevention and Eradication, WHO Pesticide Evaluation Scheme, Protection of the Human Environment Programme on Chemical Safety (2005). Safety pyrethroids for safety use.

\section{Publisher's Note}

Springer Nature remains neutral with regard to jurisdictional claims in published maps and institutional affiliations. 